Cadernos de Literatura em Tradução, n. 5, p. 105-107

\title{
Traduzindo Clarice Lispector: um exercício de diferença
}

\author{
Leila Cristina de Mello Darin
}

\begin{abstract}
Para traduzir o conto Um dia a menos (1979) de Clarice Lispector -tradução que mais adiante apresento -, recorri à consulta de artigos, estudos, entrevistas e teses na busca por delinear um parâmetro daquilo que a crítica especializada tem realçado e valorizado na prosa da escritora (1). Li também diversos de seus contos, romances e crônicas e examinei alguns de seus textos traduzidos para o inglês, como The Apple in the Dark - brilhante tradução de A Maçã no Escuro (1970) por Gregory Rabassa -, e Family Ties (Laços de Família, 1960), na excelente tradução de Giovanni Pontiero, que, por sua tradução do conto Amor, recebeu, em 1968, o Prêmio da Canning House of London (2).

Segundo minha leitura (evidentemente informada por tantas outras leituras), Clarice põe em discussão a tensa relação entre linguagem e vida, entre ser e dizer. Ela mostra que a palavra almeja tocar o "ser", unir-se apaixonadamente a ele sem, contudo, jamais expressá-lo em sua totalidade. A palavra não pode traduzir a totalidade da experiência/do sentimento/do pensamento, mas, mesmo ciente de que a palavra a "trairá", Clarice cria uma linguagem que tenta captar a gênese do pensamento e do sentimento. Em A Descoberta do Mundo, ela declara que busca "uma sintaxe o mais possível se aproximando e me aproximando do que estou pensando na hora de escrever" (3).
\end{abstract}


DARIN, Leila C. Traduzindo Clarice Lispector: um exercício de diferença.

Na tradução de Um Dia a Menos, conto que integra a coletânea de contos A Bela e a Fera (Nova Fronteira, publicação póstuma de 1979), procurei recriar os recursos verbais que pudessem surpreender o leitor e estimulá-lo a uma reflexão sobre a natureza da linguagem, sobre a questão da distância/aproximação entre ser e dizer.

conto trata de um domingo na vida de Margarida Flores, personagem central que tem 30 anos, é virgem, vive na mesma casa em que nasceu, não tem amigas nem namorado, não trabaIha e cuja única companhia é a empregada, que acaba de sair de férias para ver o filho. Toda a "ação" do conto (se é que se pode falar assim) gira em torno das atividades de M. Flores nesse domingo, em que não tem absolutamente nada para fazer: "Teve preguiça do longo dia que se seguiria: nenhum compromisso, nenhum dever, nem alegrias nem tristezas." (4)

Magistralmente, o conto trabalha alguns temas sempre presentes na obra clariceana, vinculando-os de tal maneira que aparecem praticamente sobrepostos: a busca da identidade, a solidão, o acaso e a morte. Clarice não fala abertamente destes temas, apenas os sugere sutilmente através de uma linguagem criativa que deseja aproximar-se ao máximo daquilo que ela quer dizer. Por exemplo, para falar do destino, ela constrói uma linguagem também movida pelo acaso, de tal maneira que alguns pensamentos da personagem interrompem a narrativa, desafiando a lógica seqüencial linear. $\bigcirc$ pensamento que inaugura o conto pode perfeitamente se encaixar em outros momentos da estrutura narrativa, nos intervalos vazios da rotina banal de $\mathrm{M}$. Flores, instigando o leitor a engajar-se no percurso irregular de sua própria introspecção e memória, no trajeto incerto de seu próprio dia. $\bigcirc$ acaso, que está presente na construção da própria narrativa, está em sintonia com o destino de Margarida Flores: "Aliás, por mero acaso ela não era muitas coisas. E por mero acaso havia nascido." (5)

A morte, no conto, é o grande momento de revelação da 
identidade de Margarida Flores. Ao longo de seu domingo a menos, o destino vai sendo sutilmente delineado pela personagem, em uma discreta e inquietante preparação para o instante fatal: 0 grande encontro consigo mesma. Desta maneira, a opção que desde o início vinha subversivamente se delineando nos fragmentos de pensamentos que a rotina mais banal não logrou deter é de repente concretizada: copo após copo tomou todas as pílulas de três frascos de vidro, herança de sua mãe: "Mas no segundo frasco pensou pela primeira vez na vida: Eu. E não era um simples ensaio: era na verdade uma estréia. Toda ela enfim estreava." (6)

É com a proximidade da Morte que sua consciência se ilumina e ela experimenta a totalidade de sua existência, a força de seu ser. Morrer e ser ocorrem ao mesmo tempo: "Morrer é uma sensação boa".

Deixou-se cair de través na cama onde a tinham gerado. Era um dia a menos. (7)

Ao traduzir "Deixou-se cair de través na cama onde a tinham gerado" procurei assinalar em inglês a concepção da morte como momento de revelação, desmembrando o pronome reflexivo herself (equivalente a "se" em "deixou-se") para colocar em evidência o SELF, o EU:

She lacked the strenght to go to her own bedroom: she let her self fall across the bed on which she had been procreated.

A opção por "her self" almeja imprimir à tradução para o inglês uma leitura pessoal do conto e da obra de Clarice Lispector. Minhas intervenções se coadunam com as diretrizes fundamentais que orientam meu trabalho: como tradutora estabeleço prioridades e critérios e adivinho nas palavras da escritora um sentido implícito que me arrisco a dizer.

Sem dúvida, sei que o leitor estrangeiro lerá meu texto de Clarice à luz de suas próprias motivações. Escrever é inevitavelmente difundir diferenças. $\bigcirc$ grande paradoxo, entretanto, é que desejei alcançar, ao traduzir o conto, a "essência" de Clarice 
DARIN, Leila C. Traduzindo Clarice Lispector: um exercício de diferença.

Lispector, seu valor literário, seu modo singular de significar, e, uma vez realizada a tradução, constato que inevitavelmente transformei Clarice, dando a ela nova voz, novo corpo lingüístico, e semeando para os leitores de língua inglesa, uma série infinita de possibilidades de significação.

\section{NOTAS}

(1) Uma discussão aprofundada dos critérios e da concepção de tradução que embasam minha tradução, bem como os comentários detalhados sobre a tradução do conto, encontramse em minha tese de doutoramento A tradução como busca e diferença: um diálogo teórico-prático com textos de Clarice Lispector, PUC-SP, 1993.

(2) Apud SÁ, O. de A Escritura de Clarice Lispector. Rio de Janeiro: Vozes, 1979, p. 240.

(3) LISPECTOR, C A Descoberta do Mundo. Rio de Janeiro: Nova Fronteira, 1984, p. 475.

(4) LISPECTOR, C. Um dia a menos. A Bela e a Fera. Rio de Janeiro: Nova Fronteira, 1979, p. 119.

(5) Op. Cit., 120.

(6) Op. Cit., p: 129

(7) Op. Cit., p. 130. 
Cadernos de Literatura em Tradução, n. 5, p. 105-107

\section{A DAY LESS \\ (A short story by Clarice Lispector)}

I suspect death is close. Death?

Will these long days ever end?

So I wonder, still, quiet.

Is death a joke? Is it a trick life plays on us? Is it persecution?

So it is.

The day began at 4 a.m., she always woke up early, and found a thermos flask full of coffee waiting for her in a small dinning-room. She drank a cup of lukewarm coffee and was going to leave it there for Augusta to wash when she remembered that old Augusta had asked for a month's leave to see her son.

A feeling of laziness came over her as she thought of the day that would follow: no appointments, no duties, neither happiness nor sorrow. So she sat down wearing her oldest dressing gown, as she never expected any visitors. But to be so poorly dressed - clothes that had belonged to her dead mother - made her uneasy. She got up and put on a pink and white spotted pyjamas that Augusta had given her on her last birthday. That was better. And it got better still when she sat down in the armchair recently covered in purple (Augusta's choice) and lit her first cigarette of the day. It was an expensive cigarette, of light-coloured tobacco, with a long cigarette-holder, status symbol of someone who wasn't her by any chance. She wasn't a lot of things by any chance. In fact, she was even born by mere chance.

And then what?

And then. 
DARIN, Leila C. Traduzindo Clarice Lispector: um exercício de diferença.

And then.

That's it.

That's just the way it is.

Isn't it?

And then, just then it suddenly dawned on her: so then that's just the way it is. Augusta had told her things would get better then. Even so she had had enough of that's the way it was.

She remembered that the newspaper she subscribed to should be at her front door. There she went, kind of excited, you never know what the news will be, if a minister of Indochina has committed suicide, or if a lover, threatened by the bride's father, has ended marrying.

But the newspaper wasn't there: that devil of an enemy, her neighbour, must have already taken it. It was a constant battle to see who would first get to the paper on which, however, her name was clearly printed: Daisy Flowers. And the address. Whenever she casually looked at her printed name she remembered her nickname at primary school: Daisy Funeral Flowers. Why didn't it occur to anyone to give her a nickname like Daisy Garden Flowers? But things weren't simply on her side. She had a silly thought: even her small face was on one side. In a strange angle. She never considered herself pretty or ugly. She was obvious.

And then.

And then there were no money problems.

And then there was the telephone. Would she call up anyone? But whenever she did call she had the impression she was being a bother. Maybe she would interrupt a sexual embrace. Or else she would be a bother because she had nothing to say.

And what if someone called her? She would have to control the tremble and excitement in her voice, due to the satisfaction of someone having called her.

She imagined the following: Tring-Tring.

"Hello? Yes?"

"Is that Daisy Garden Flowers?" 
Faced with such an attractive masculine voice, she would answer:

"Daisy Flowers of Flowery Forests."

And the musical voice would invite for an afternoon tea at the Café Colombo. She just remembered that nowadays men no longer invited women to tea and toasts but for a drink. That would complicate things: to go for a drink you had to be dressed in a more daring, mysterious, personal manner... She wasn't personal. That disturbed her a little, though not much.

And, besides, the telephone didn't ring.

And then. She was what she saw when she looked in the mirror. She seldom looked in the mirror, as if she already knew herself well. She ate too much. She was plump and pale and flabby in her plumpness.

And then she decided to tidy up the drawer of panties and bras: she was exactly the kind that tidies up drawers of panties and bras and she felt good in the delicate task. If she were married her husband would have a neat row of ties in perfect order arranged according to the variations in colour, or according to.... According to anything. For there is always some guiding criterion to be followed. As for herself, she was guided by the fact that she wasn't married, that she had the same maid ever since she was born, that she was a woman of thirty, little lipstick, dull clothes... And what else? She hurriedly avoided "and what else" for this question would lead to a very selfish and uneasy sentiment: she would feel alone, and that was a sin because he who has God is never alone. She had God, for wasn't He the only thing she had? Apart from Augusta.

So, she took a shower that gave her so much pleasure that she couldn't avoid thinking what other bodily pleasures would be like. To be a virgin at the age of thirty had no remedy, unless she were raped by some criminal. After the shower and the thoughts, talcum, talcum, a lot of talcum powder. And lots and lots of deodorants: she doubted if anyone in Rio de Janeiro smelt less than she did. She was the most scentless of all creatures. And she 
DARIN, Leila C. Traduzindo Clarice Lispector: um exercício de diferença.

left the bathroom in a light minuet, so to speak.

And then.

And then she saw with great satisfaction, on the kitchen clock, that it was already eleven o'clock in the morning. How time flew since 4 a.m.! It was a gift from the gods that time flew by! While she heated the whitish thick-skinned pieces of chicken from dinner, she turned on the radio and caught a man in mid-thought: "flute and viola"... said the man and suddenly she could bear it no more and turned off the radio. As if "flute and viola" were in fact her secret, desired and unattainable essence. She took courage and murmured: "flute and viola".

Having switched off the radio and specially the thought, a silence fell over the rooms: as if someone somewhere had just died... But fortunately there was the noise coming from the pan heating the pieces of chicken, which, perhaps, might gain some colour and taste. She started eating. But she soon realised her mistake: having taken the chicken out of the fridge and having heated it just a little, there were parts in which the fat was jelly-like and cold, and others in which it was burnt and fried up.

Yes.

And dessert? She heated up a bit of the morning coffee and flavoured it with some bitter saccharin to avoid getting fat. How it would be lovely to be almost emaciated.

And then.

She remembered out of the blue that there were millions of hungry people, in her country and elsewhere. She would feel uneasy every time she ate.

And then.

And then! How could she have forgotten the television? Ah, without Augusta she forgot everything. She switched it on, hopefully. But at that time of the day they only showed old westerns, heavily sprinkled with ads about onions, disposable bags, soft drinks which must be nice but fattening. She decided to light a cigarette. That would make things better for it would turn her into a painting 
at an exhibition: Woman Smoking in front of Television. Only after quite a long time did she realise that she wasn't even looking at the TV and that she was only wasting electricity. She turned off the TV switch, relieved.

And then.

And then?

And then she decided to read old magazines, which she hadn't done for a long time. They were all piled up in her mother's room since her death. But they were a bit too old, some dating from the time her mother was still single, fashions were different then, men wore moustaches, ads of girdles to make waists slimmer. And most important, men wore moustaches. She withheld herself again without the willpower to throw them away, since they had belonged to her mother.

And then.

Yes, and then?

And then, she boiled water for some tea, all the while conscious that the telephone didn't ring. If at least she had had some workmates, but she didn't work: her parents' pensions satisfied her needs. Besides, she didn't have good handwriting and she thought that without good handwriting you couldn't get a job.

She drank the tea hot, chewing on small dry toasts that scratched her gums. They could be nicer with some butter. But of course butter was fattening besides the fact that it raised one's cholesterol level, whatever that modern word meant.

As she was just breaking the third toast with her teeth she had a habit of counting things, she had a thing about order, which was after all harmless and even amusing - as she was going to eat the third toast... IT HAPPENED! I could swear, she said to herself, I could swear I heard the telephone ring. She spat out the piece of the third toast onto the tablecloth and, not to give the impression that she was hasty or eager, she let it ring four times, and each time it rang, she felt a stab of pain in her heart for whoever it was could hang up thinking there was no one at home! At this 
DARIN, Leila C. Traduzindo Clarice Lispector: um exercício de diferença.

terrifying thought she suddenly hurried to answer it on the fourth ring and managed to say in a nonchalant voice:

"Hello..."

"Excuse me" - said a feminine voice which judging by its tired hoarseness must be over eighty years old - "could you call Jane to the set (nobody called a phone a 'set' anymore) for me? My name is Constance!"

"Madame Constance, I am sorry to inform you that no one called Jane lives here, I know that Jane is a very romantic name, but there is no Jane here, I'm afraid", said she not without despair because of Madame Constance's commanding voice.

"But isn't that General Isidro Street?"

This made things worse.

"Yes, it is, but what telephone number did you dial? Pardon me? Mine? But I assure you I have lived here for exactly thirty years, ever since I was born, and no young lady called Jane has ever lived here!"

"Young lady you say? That is a good one! Jane is a year older than I and if she hides her age that is no problem of mine!"

"Maybe she doesn't hide it, Madame Constance."

"Hide her age? I am sure she does! But would you please tell her to come to the set right now!"

"I... I... what I was trying to say is that our family was the first and the only one to live in this house and I assure you, I swear by God, that no lady called Jane has ever lived here, and I am not saying that Jane doesn't exist, but here, Ma'am, t-h-e-r-e-i s-n-o..."

"Don't be rude, you silly girl! By the way, what is your name?"

"Daisy Garden Flowers."

"Why? Are there flowers in the garden?"

"Ha, ha, ha, you have a great sense of humour! No, there are no flowers in the garden, I just have a flowery name!" 
"Does it help you in any way?"

Silence.

"Well, I don't know what to say because I've never thought about it before, I just know to talk about things I've already thought about!"

"Well, then do concentrate and bring to your mind the name of Jane and you'll see you'll know what to say."

"I'm concentrating... I'm concentrating... ah! I've got it! My nursemaid's name is Augusta!"

"But for God's sake, I'm losing my patience, I don't want any nursemaid, I want J-A-N-E!"

"I don't want to be rude but my mother always said that people who insist are ill-mannered, I'm sorry."

"Ill-mannered? Me? Brought up in Paris and London? Can you at least speak French or English, so that we can practise a little?"

"I only speak the language of Brazil, Ma'am, and I think it's time you hung up because my tea must be ice-cold by now."

"Tea at three in the afternoon? It's obvious you haven't the slightest class, and I thought you could even have studied in England and that you at least knew what time one is supposed to have tea!"

"The tea is because I had nothing to do Madame Constance. Now I beg you, for God's sake, stop torturing me, I implore you on my knees to hang up so that I can have my Brazilian tea."

"OK but you don't have to cry over that, Miss Flowers, my sole intention was to talk to Jane to invite her for a game of bridge. Ah! I have an idea! Since Jane has gone out, why don't you come over for a card game, just small change? Well? What do you think? Don't you find it tempting? What about entertaining an old lady?"

"Good Lord, I don't play any games at all."

"But how come you don't?" 
DARIN, Leila C. Traduzindo Clarice Lispector: um exercício de diferença.

"That's just it: How come."

"And to what do you attribute this lack in your education?"

"You see, my father was strict: he didn't allow any kind of card playing at home."

"Your father, your mother and Augusta were too oldfashioned if you don't mind my saying and I think..."

"Of course I mind! Now if you'll excuse me, Ma'am, I am the one who is going to hang up."

Wiping her eyes, she felt relieved for a moment and a thought occurred to her so new that it didn't seem to be her own: it sounded as evil as one of Madame Constance's ideas... She would take the receiver off the hook in case Madame Constance was as constant as her name and decided to call back to ask for that damned Jane. She blew her nose. If she weren't so well mannered, the things she would have said to that Constance! She was already even regretting the things she hadn't said just because of her good manners.

Yes. The tea was ice-cold.

And it had a strong taste of saccharin. The third toast spat on the tablecloth. The afternoon ruined. Or was it the day that was ruined? Or was it life that was ruined? She had never stopped to think whether she was happy or not. So, instead of tea, she ate a somewhat sour banana.

And then.

And then. And then it was four p.m..

And then five.

Six.

Seven: dinnertime!

She would have liked to eat something else and not yesterday's chicken but she had learnt not to waste food. She ate a dry chicken leg with toasts. As a matter of fact, she wasn't hungry. Only on a few occasions did she eat well with Augusta, because they chatted, chatted and ate, oh, they didn't follow their diets and 
they didn't even grow fat! But Augusta was going to be away for a month. A month is a lifetime.

Eight o'clock. She could already go to bed. She brushed her teeth for quite a while, thoughtfully. She put on a well-worn threadbare cotton nightdress, one of those comfortable ones, made by her mother. She got into the bed, under the blanket.

Eyes wide open.

Eyes wide open.

Eyes wide open.

Just then she thought of the bottles of sleeping pills that had belonged to her mother. She remembered her father: careful with the dose, Leontine, an overdose can be fatal. Who me? Leontine would answer, I don't want to leave this good life so soon, I only take two little pills, enough to have a good night's sleep and to wake up all rosy for my dear husband.

That's it, thought Daisy of the Flowers in the Garden, have a good night's sleep and wake up all rosy. She went to her mother's bedroom, opened the drawer on the left side of the big double bed - and, sure enough, she found three bottles, full of tiny little pills. She would take two pills to wake up all rosy. She had no evil intention. She fetched a jug and a glass. She opened one of the bottles: she took out two little pills. They tasted of mould and sugar. She didn't notice in herself the slightest evil intention. But no one in the world will ever know. And no one will ever be able to say whether she did it because she was unbalanced, or because perhaps she'd never been so balanced: glass after glass she swallowed all the pills from the three big bottles. But on the second bottle she thought for the first time in her life: "Me". And it wasn't a mere rehearsal: it was actually a debut. Her whole being finally came into existence. And even before she had taken them all, she already felt something in her legs, a wonderful sensation such that she had never felt. She didn't even know it was Sunday. She lacked the strength to go to her own bedroom: she fell across the bed on which she had been procreated. It was a day less. She vaguely thought: if only Augusta had left a raspberry pie for me. 